\title{
CHARACTERIZATION OF THE VACUUM PLASMA SPRAYED VPS-Ti/TIC COMPOSITE COATING
}

\author{
Mihailo R. Mrdak \\ Research and Development Center IMTEL Communications a.d., \\ Belgrade, Republic of Serbia, \\ e-mail: miki@insimtel.com, \\ ORCID iD: (i)http://orcid.org/0000-0003-3983-1605
}

DOI: 10.5937/vojtehg66-15306; https://doi.org/10.5937/vojtehg66-15306

\author{
FIELD: Chemical Technology \\ ARTICLE TYPE: Original Scientific Paper \\ ARTICLE LANGUAGE: English
}

\section{Summary:}

The paper analyzes the VPS - Ti / TiC composite coating. The powder was deposited at low pressure with an F4 plasma gun produced by Plasma Technik AG because of the influence of the environment on powder oxidation. The main goal of the work was to prevent low-pressure decomposition of TiC cubic carbide into $\mathrm{TiO}_{2}$ and $\mathrm{NiTiO}_{3}$ oxides that reduce: adhesion, cohesive strength, TiC hardness, and abrasion resistance to wear. The mechanical properties and the structure of the $\mathrm{Ti} /$ TiC coating were analyzed in accordance with the Pratt \& Whitney standard. The microhardness values of the coating layers were in the range of 750-837 $\mathrm{HV}_{0.3}$, and the substrate/coating bond strength was 84 $\mathrm{MPa}$. The coating microstructure was examined by the light microscopy technique. The distribution of TiC in the Ti base is uniform and the deposited layers are obtained without segregation effects. The coating structure consists of titanium layers with $\beta$ - Ti and $\alpha$ - Ti modifications and TiC cubic layers. In the microstructure, there are unmelted TiC particles present in a smaller share as well as micropores that did not affect the coating strength. The tests showed that the VPS - Ti / TiC composite coating has good mechanical properties and a good microstructure, which fully enables its application on substrates of biomedical implants.

Keywords: microstructure, coatings.

\section{Introduction}

Materials used for biomedical implants must meet a number of requirements which are often mutually exclusive. Different parts of the

ACKNOWLEDGEMENT: The author is thankful for the financial support from the Ministry of Education and Science of the Republic of Serbia (national project OI 174004, TR 34016). 
elements require different material properties. These factors often make the production of medical implants harder when using one type of material. Many implant elements, such as knee replacements, only include relative movement between the components while functioning. In such conditions, polyethylene applied on supporting metal surfaces is currently widely used. However, although polyethylene as a whole is biologically inert in the body, microscopic polyethylene particles formed by wear may be poisonous if present in large quantities and they can lead to osteolysis (Pancanti et al, 2003, pp.777-785), (Atala et al, 2010), (Amstutz \& Le Duff, 2012, pp.275-282), (Hamilton et al, 2013, pp.96100). This has led to an increasing interest in the fabrication of supporting surfaces of metal-on-metal implants, especially in applications involving a large contact surface (Liu et al, 2005, pp.319-328), (Haruna et al, 2017, pp.95-101), (Goldsmith et al, 2000, pp.39-47), (Xia et al, 2017, pp.1205-1217). The metal-on-metal approach requires that the supporting surfaces be extremely hard and resistant to wear. Manufacturing a whole implant out of a hard material is not acceptable, because such hard materials would be too brittle to use. The best approach is the application of appropriate hard surface layers on the supporting surfaces of the implant. This approach allows the production of implants with biocompatible materials with the desired properties, and the surface requirements are met with biocompatible hard surface layers. Although the application of surface coatings is certainly an advantage, which is a great benefit in the process of implant making, there are, however, some issues relating to the coating materials that must satisfy some of the requirements, such as: coating material must be biocompatible, coatings must not be brittle or prone to other damage, coatings should have adequate hardness and wear resistance, and coating material should be metallurgically compatible with the carrier material of the implant. Most coating materials, such as carbides, borides, nitrides, and oxides $\left(\mathrm{Al}_{2} \mathrm{O}_{3}, \mathrm{ZrO}_{2}, \mathrm{CaO}\right.$, etc.), easily meet hardness and abrasion resistance requirements, but they are brittle and often not metallurgically compatible with metal substrates of implants. It is difficult to apply hard monophase non-metallic materials on metal substrates due to residual stresses at the interface and inside the coating; this causes brittleness, cracking of coating particles, peeling and separating coating parts from the metal substrate of the implant. For example, depositing a coating of pure $\mathrm{TiC}$ on the $\mathrm{Ti}$ alloy substrate is undesirable because the coating cracks (Liu \& DuPont, 2003, pp.13371342). This has led to the use of composite coatings consisting of a tough metal substrate and hard non-metallic materials evenly dispersed 
in the metal substrate. In this way, a coating with the desired characteristics can be produced. A soft metal substrate provides toughness to the coating as well as the metallurgical compatibility / bonding with the substrate, while hard non-metallic material reinforces the coating and provides adequate hardness and resistance to wear. Another important issue is a coating application method. In this respect, a coating application method or process should enable the production of homogeneous and thick composite coatings. The coating must be able to achieve metallurgical bonding to the base material in order to achieve adequate adhesion and to allow a minimum heat input so as not to damage the microstructure and the mechanical properties of the base material. Today, $\mathrm{Ti} / \mathrm{TiC}$ composite coatings are extremely suitable for application on parts of metal-on-metal implants exposed to excessive wear. These types of coatings can be especially used on commercial titanium alloys for the production of high performance implants. The method of protecting implant parts consists of the deposition of a mechanical mixture of commercial $\mathrm{Ti}$ and $\mathrm{TiC}$ powders of $\mathrm{Ar}$ inert gas at low pressure by the plasma spray process in a vacuum. Depending on the working conditions of the coating, the VPS process allows the deposition of composite coatings in different quantitative relationships between carbide and metal. At low pressure of the inert gas, the reaction of metal and carbide with the air is completely eliminated. The advantage of the process is the application of the transferred arc which cleans and preheats the substrate surface prior to depositing the powder thus increasing the adhesion and cohesive strength (Mrdak, 2017, pp.30-44). The properties of coating layers are directly connected to powder technology and powder deposition parameters. TiC is dark gray, with a low density of $4.93 \mathrm{~g} / \mathrm{cm}^{3}$ and a high melting temperature of $3140{ }^{\circ} \mathrm{C}$. TiC particles have shown great potential as a phase that reinforces the composite material due to its high hardness level, high modulus, low density and high thermal stability. TiC-based cermets have excellent resistance to wear, high temperature, chemical corrosion, oxidation, as well as a low coefficient of friction and density (Cai et al, 2013, pp.1681-1688). TiC coatings have superior resistance when exposed to abrasion. The $\mathrm{Ti} / \mathrm{TiC}$ composite base can be another metal or alloy depending on different needs and applications. Due to its excellent corrosion resistance, high strength to weight ratio and biocompatibility, titanium is used as the carrier material for the fabrication of metal parts of implants in a large number of applications (Okazaki et al, 2001, pp.599607 ). Ti has a polymorphism property, since it crystallizes from the liquid state to $1665{ }^{\circ} \mathrm{C}$ in a $\beta$-spatially centered cubic lattice, and when cooled 
further to $882{ }^{\circ} \mathrm{C}$ it goes into an $\alpha$-hexagonal tightly packed grid. Titanium is a metal with a low density of $4.5 \mathrm{~g} / \mathrm{cm}^{3}$, which in combination with good mechanical properties, such as high strength and hardness, gives high specific strength. The Ti/TiC coating consists of a mixture of coarse nonmolten, partially molten and completely molten TiC particles uniformly distributed in the titanium base with $\beta$-Ti and $\alpha$-Ti modifications. With the increase of the TiC content in the coating, the coating hardness and resistance to wear increases. Besides by the TiC content, the coating microhardness is also affected by the content, size and distribution of micropores in the deposited layers. The coating friction coefficient depends on the content of carbides in the coating. When the content of TiC particles increases, the coefficient of friction of composite coatings decreases. The friction coefficient decreases with the increase of the content of TiC particles in the coating.

The main objective of the paper is to deposit layers of coating with primary cubic titanium carbide (TiC) in a vacuum at low pressure of inert gas, which gives excellent resistance to wear, high temperature, oxidation and corrosion. Studies have shown that the VPS - Ti/TiC coating has good mechanical properties and a microstructure in which there are no oxides of $\mathrm{TiO}_{2}$ and $\mathrm{NiTiO}_{3}$. The coating layers have adhesion and cohesion strength values which are in agreement with the coating microstructure in which the primary cubic carbide TiC dominates, thus making such a coating capable of modifying the surface of biomedical implants.

\section{Materials and experimental details}

A VPS-Ti/TiC composite coating was made from a mixture consisting of a commercially pure $\mathrm{Ti}$ powder of $60 \mathrm{wt} \%$ and $\mathrm{TiC}$ of 40 $w t \%$. The morphology of powder particles was examined on a scanning electron microscope (SEM). Powder particles are of irregular shape with sharp edges, obtained by a grinding technique with a powder range ranging from $45 \mu \mathrm{m}$ to $150 \mu \mathrm{m}$. Figure 1 shows a SEM micrograph of $\mathrm{Ti}$ powder particles, and Figure 2 shows a SEM micrograph of TiC powder particles. The substrates on which the layers were deposited were made of steel Č.4171 (X15Cr13 EN10027).

In order to test the microhardness of the Ti-TiC composite coating layers, $70 \times 20 \times 1.5 \mathrm{~mm}$ samples were made, while the samples for testing the bond strength had the dimensions of $\varnothing 25 \times 50 \mathrm{~mm}$. The microhardness of the layers was assessed by the $\mathrm{HV}_{0.3}$ method and the bond strength by tensile testing. 


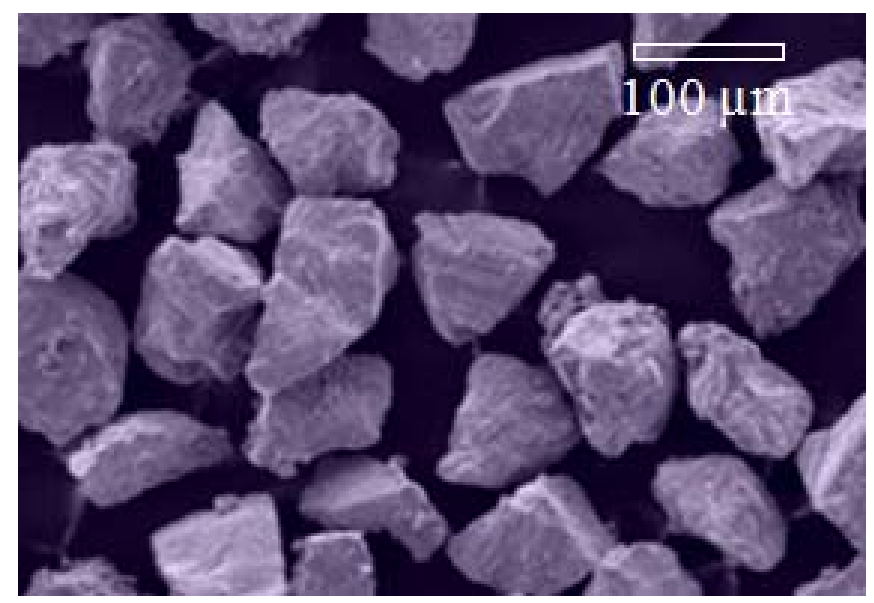

Figure 2 - (SEM) Shape of TiC powder particles

Puc. 1 - (SEM) Форма частиц порошка Ti

Слика 1 - (CEM) Облик честица праха Ti

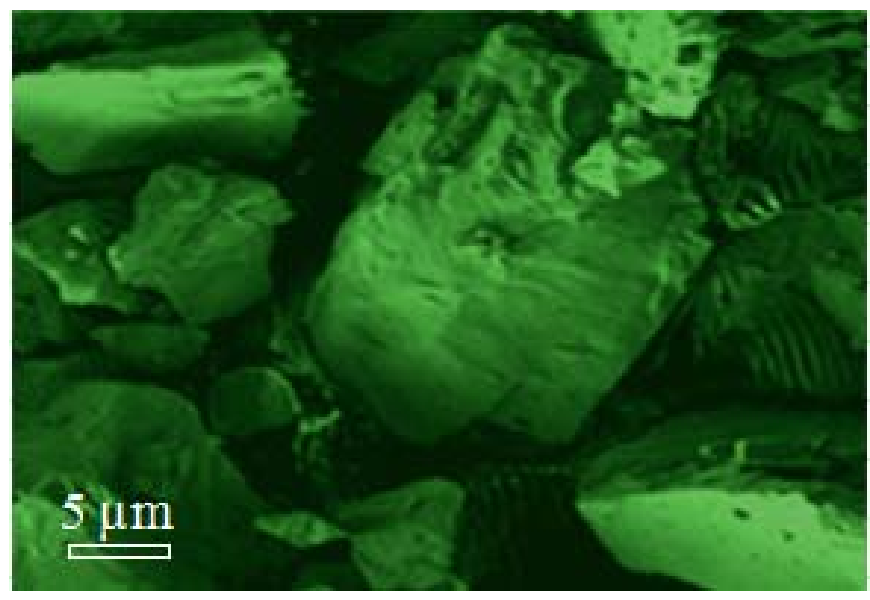

Puc. 2 - (SEM) Форма частиц порошка ТiC

Слика 2 - (CEM) Облик честица праха TiC

In order to assess the coating homogeneity, the layer microhardness was measured in the direction along the lamellae, in the middle and at the ends of the samples. Five readings were carried out at three measuring points, and the microhardness range from the minimum to maximum value was displayed. The coating/substrate interface strength was tested by tensile testing with a tensile speed of $1 \mathrm{~mm} / 1 \mathrm{~min}$. Five test 
specimens were used and the average values were presented in the report. The microstructure of the deposited layers was examined on a light microscope. The share of micropores in the coating was analysed by processing 5 micrographs at a magnification of 200x, and the report shows the average pore content in the coating. The coating mechanical and microstructural characteristics were examined in accordance with the standard (Pratt \& Whitney, 2002).

Prior to the deposition of the mechanical mixture of $\mathrm{Ti}$ and $\mathrm{TiC}$ powders, the surfaces of the substrate were roughened with white corundum particles of $0.7-1.5 \mathrm{~mm}$. The powder was deposited on the Plasma Technik AG system with a F4 plasma gun. The microprocessor unit of the VPS Plasma Technik AG has a program for depositing a powder mixture. All process parameters were included in the program, such as: chamber vacuuming, plasma gas flow, cleaning the substrate with a transferred arc, powder mixture flow, coating deposition rate, substrate cooling and vacuum chamber ventilation. The substrate surface was cleaned with a transferred arc using $\mathrm{Ar} / \mathrm{He}$ gases. The powder mixture was deposited with a mixture of $\mathrm{Ar} / \mathrm{H}_{2}$ plasma gases. The coating was deposited with a thickness of 90-100 $\mu \mathrm{m}$.

The plasma spray parameters of the Ti-TiC powder deposition on the samples are shown in Table1.

Tabela 1 - VPS parameters of the deposition of the Ti-TiC powder mixture

Таблица 1 - VPS параметры нанесения смеси порошков Ti-TiC

Табела 1 - VPS параметри депозиције мешавине праха Ti-TiC

\begin{tabular}{|l|l|l|}
\hline \multirow{2}{*}{ Parameters } & Values \\
\cline { 2 - 3 } & Cleaning arc & Spraying \\
\hline Plasma current, I $(\mathrm{A})$ & 500 & 745 \\
\hline Plasma Voltage, $\mathrm{V}(\mathrm{V})$ & 65 & 74 \\
\hline $\begin{array}{l}\text { Primary plasma gas flow rate, } \mathrm{Ar} \\
(\mathrm{I} / \mathrm{min})\end{array}$ & 50 & 40 \\
\hline $\begin{array}{l}\text { Secondary plasma gas flow rate } \\
\mathrm{He}^{(1)}, \mathrm{H}_{2}^{(2)},(\mathrm{l} / \mathrm{min})\end{array}$ & $10^{(1)}$ & $8.5^{(2)}$ \\
\hline Carrier gas flow rate $(\mathrm{l} / \mathrm{min})$ & -- & 4 \\
\hline Powder feed rate, $(\mathrm{g} / \mathrm{min})$ & -- & 15 \\
\hline Stand-off distance, $(\mathrm{mm})$ & 290 & 270 \\
\hline Chamber pressure $(\mathrm{mbar})$ & 40 & 80 \\
\hline Nozzle diameter, $(\mathrm{mm})$ & 8 & 8 \\
\hline Speed of the gun, $(\mathrm{mm} / \mathrm{s})$ & 250 & 250 \\
\hline
\end{tabular}




\section{Results and discussion}

Along the lamellar microstructure of the $\mathrm{Ti} / \mathrm{TiC}$ coating, the microhardness values range from $750 \mathrm{HV}_{0.3}$ to $837 \mathrm{HV}_{0.3}$. The measured values indicate that the coating microstructure contains an undeveloped primary carbide phase $\mathrm{TiC}$ due to the powder deposition in an inert atmosphere of $\mathrm{Ar}$ at low pressure, which is confirmed by the analysis of the microstructure of the coating layer on a microscope (OM). Such a microhardness range of the deposited layers of the $\mathrm{Ti} / \mathrm{TiC}$ composite coating is caused by the influence of softer Ti layers, a hard TiC carbide phase, and the presence of micropores. The tensile strength of the bond between the metal substrate and the $\mathrm{Ti} / \mathrm{TiC}$ composite coating is 84 $\mathrm{MPa}$. High tensile bond strength values are generally characteristic of deposited coatings in a vacuum. The roughening of the metal substrate surface and the subsequent cleaning of the substrate surface with a transferred arc at low pressure resulted in a better adherence of molten powder particles to the substrate, which led to a high adhesion value. The values of microhardness and tensile bond strength are always in correlation with the microstructure of layers.

Figures 3 and 4 are the micrographs of the structure of the deposited layers of VPS - Ti / TiC composite coatings. The qualitative analysis has shown that there are no defects in a form of discontinuity of the deposited layers, microcracks, macrocracks and separation of the coating layers from the substrate at the interface. In some places, at the substrate/coating interface, there are dark areas formed by TiC carbide particle exctraction during the sample preparation. This effect is known as pull out and, in the micrograph, it is clearly visible that these dark areas retain the morphology of an original TiC carbide particle with its angular and sharp edges.

The boundary at the substrate/coating interface is extremely clean, indicating that the substrate surface was perfectly cleaned with a transferred arc. Dark micropores of irregular shape are present in the coating layers at the lamellar borders of $\mathrm{Ti}$ and $\mathrm{TiC}$ carbides. The average value of the share of micropores was $2.7 \%$. A smaller part of the coating contains unmelted TiC particles that are irregular in shape and darker in the micrograph. The Ti/TiC composite coating microstructure shows that the $\mathrm{Ti}$ and $\mathrm{TiC}$ layers are uniformly deposited without segregation, which is crucial for the coating good resistance to wear. 


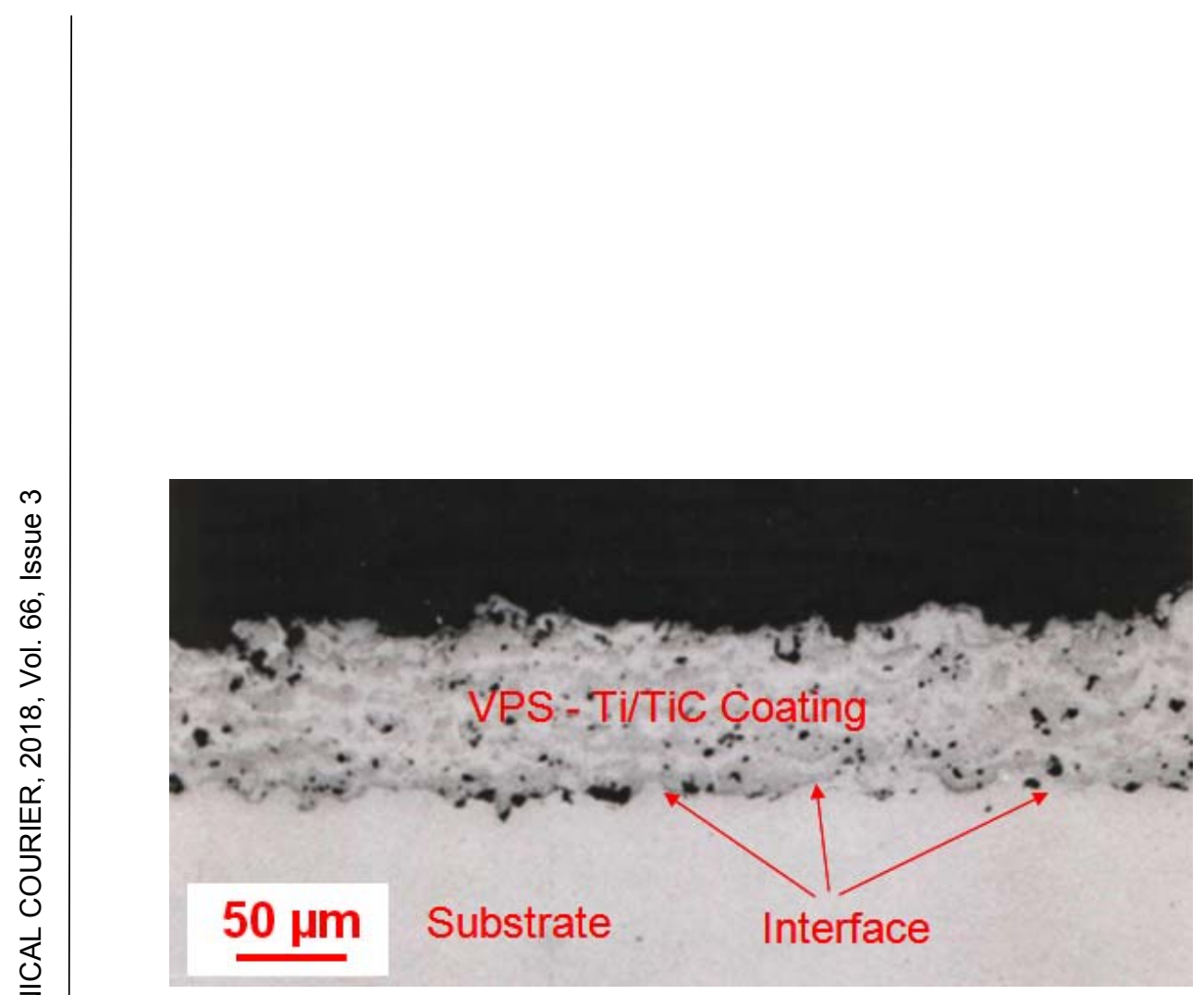

Figure 3 - (OM) Microstructure of the Ti-TiC coating in a deposited state Puc. 3 - (ОМ) Микроструктура нанесенного покрытия Ti-TiC Слика 3 - (OM) Микроструктура Ti-TiC превлаке у депонованом стању

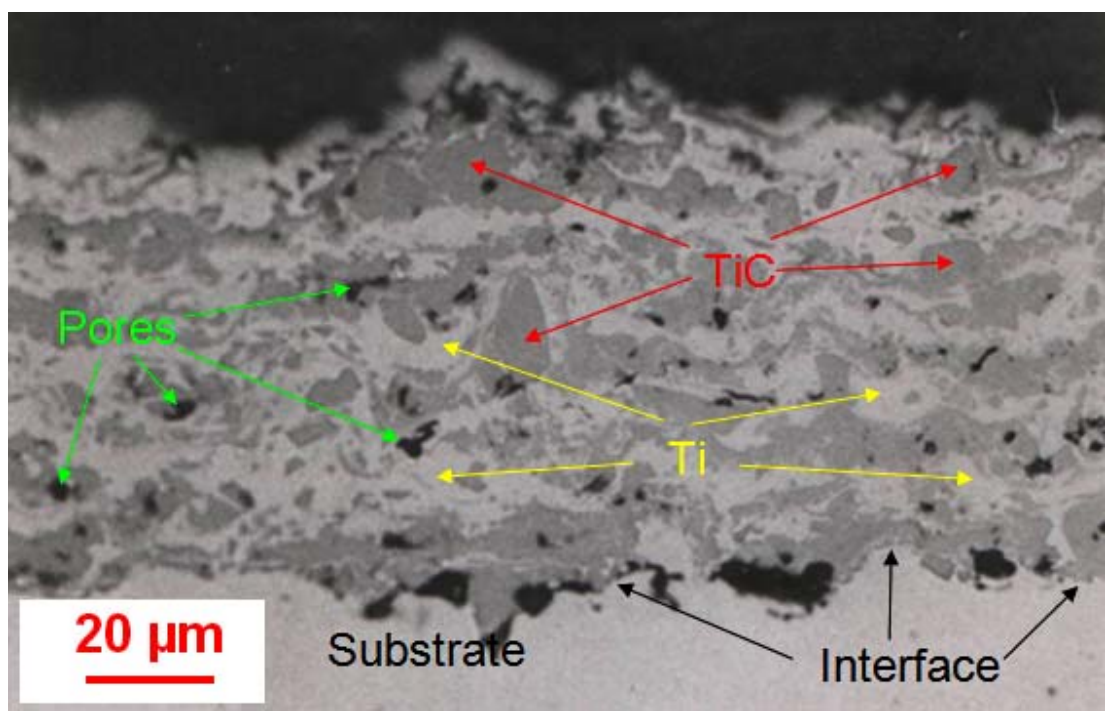

Figure $4-(\mathrm{OM})$ Microstructure of the Ti-TiC coating in a deposited state Puc. 4 - (ОМ) Микроструктура нанесенного покрытия Ti-TiC Слика 4 - (ОМ) Микроструктура Ti-TiC превлака у депонованом стању

Through the coating layers, no precipitates are observed, and longitudinal oxide lamellae are not observed at the interlamellar boundaries either. This confirms that the vacuum plasma spray process 
allows the deposition of coating layers without the content of $\mathrm{TiO}_{2}$ and $\mathrm{NiTiO}_{3}$ oxides which reduce the coating mechanical properties, thus showing a great advantage over other thermal spray processes. The microstructure of the $\mathrm{Ti} / \mathrm{TiC}$ cermet coating is lamellar with good interlamellar bonding of longitudinal Ti lamellae which form the basis of the coating composed of $\beta-\mathrm{Ti}$ and $\alpha-\mathrm{Ti}$ modifications and longitudinal lamellae of $\mathrm{TiC}$ cubic carbide. Good interlamellar bonding in the deposit increases microhardness values and fracture toughness, as confirmed by mechanical tests of the coating. The inner layers of the coating are free of microcracks. The tests have shown that the VPS - Ti / TiC composite coating has such mechanical and structural properties which allow it to be used in exploitation on parts of implants exposed to wear and corrosion of liquids of living tissues.

\section{Conclusion}

In this work, the vacuum plasma spray process was used for depositing $\mathrm{Ti} / \mathrm{TiC}$ composite coating layers. The mechanical characteristics and the microstructure of the coating in the deposited state were analyzed, based on which the following conclusions were drawn.

The vacuum plasma sprayed $\mathrm{Ti} / \mathrm{TiC}$ composite coating had the microhardness values of $750 \mathrm{HV}_{0.3}$ to $837 \mathrm{HV}_{0.3}$. The adhesion strength between the composite coating and the substrate had a high value of 84 $\mathrm{MPa}$. Cleaning the substrate surface with a transferred arc led to a better adhesion of molten particles, which reflected in the resulting adhesion value. The microhardness and adhesion strength of the Ti/TiC composite coating bond were in correlation with the microstructure of the deposited layers.

The coating microstructure is lamellar with uniformly distributed lamellae of the basic Ti coating composed of $\beta$ and $\alpha$ modifications and longitudinal lamellae of $\mathrm{Ti}$ cubic carbide. At the interlamellar surfaces, there is a share of micropores of $2.7 \%$. Through the coating layers, the segregation of the $\mathrm{TiC}$ carbide phase in the $\mathrm{Ti}$ base is not observed, which enables uniform wear of the coating in exploitation.

The vacuum plasma sprayed $\mathrm{Ti} / \mathrm{TiC}$ composite coating has good mechanical and structural characteristics, and the goal was to produce a coating of increased resistance to wear and corrosion for its application in biomedicine to modify the surface of parts of biomedical implants. 


\section{References}

Amstutz, H.C., \& Le Duff, M.J. 2012. Hip Resurfacing: a 40-Year Perspective. HSS Journal, 8(3), pp.275-282. Available at: https://doi.org/10.1007/s11420-012-9293-9.

Atala, A., Lanza, R., Thomson, J., \& Nerem, R. 2010. Principles of Regenerative Medicine, 2nd Edition. [e-book]. Elsevier B.V. Available at: https://www.elsevier.com/books/principles-of-regenerative-medicine/atala/978-012-381422-7

Cai, B., Tan, Y., He, L., Tan, H., \& Gao, L. 2013. Tribological properties of TiC particles reinforced Ni-based alloy composite coatings. Transactions of Nonferrous Metals Society of China, 23(6), pp.1681-1688. Available at: https://doi.org/10.1016/S1003-6326(13)62648-5.

Goldsmith, A.A.J.,_Dowson, D., \& Isaac, G.H. 2000. A comparative joint simulator study of the wear of metal-on-metal and alternative material combinations in hip replacements. Proceedings of the Institution of Mechanical Engineers, Part H: Journal of Engineering in Medicine, 214(1), pp.39-47. Available at: https://doi.org/10.1243/0954411001535228.

Hamilton, W.G., Parks, N.L., \& Saxena, A. 2013. Patient-specific instrumentation does not shorten surgical time: a prospective, randomized trial. The Journal of Arthroplasty, 28(8), pp.96-100. Available at: https://doi.org/10.1016/j.arth.2013.04.049.

Haruna, M.N., Jinb, Z., \& Syahroma, A. 2017. Influence of Lubrication Performance on Wear Factor in Metal-on-Metal Hip Joint Replacement using Numerical Analysis. Procedia Engineering, 68, pp.95-101. Available at: https://doi.org/10.1016/j.proeng.2013.12.153.

Liu, F., Jin, Z.M., \& Hirt, F. 2005. Effect of Wear of Bearing Surfaces on Elastohydrodynamic Lubrication of Metal-on-Metal Hip Implants. Proceedings of the Institution of Mechanical Engineers, Part H: Journal of Engineering in 219(5), pp.319-328.

Available

at: https://doi.org/10.1243/095441105X34356.

Liu, W., \& DuPont, J.N. 2003. Fabrication of Functionally Graded TiC/Ti Composites by Laser Engineered Net Shaping. Scripta Materialia, 48(9), pp.1337-1342. Available at: https://doi.org/10.1016/S1359-6462(03)00020-4.

Mrdak, M.R. 2017. Mechanical properties and the microstructure of the plasma-sprayed $\mathrm{ZrO}_{2} \mathrm{Y}_{2} \mathrm{O}_{3}$ / $\mathrm{ZrO}_{2} \mathrm{Y}_{2} \mathrm{O}_{3}$ CoNiCrAlY / CoNiCrAlY coating. Vojnotehnički glasnik / Military Technical Courier, 65(1), pp.30-44, Available at: https://doi.org/10.5937/vojtehg65-10586.

Okazaki, Y., Nishimura, E., Nakada, H., \& Kobayashi, K. 2001. Surface analysis of Ti-15Zr-4Nb-4Ta alloy after implantation in rat tibi. Biomatreials, 22(6), pp.599-607. Available at: https://doi.org/10.1016/S0142-9612(00)00221-0.

Pancanti, A., Bernakiewicz, M., \& Viceconti, M. 2003. The primary stability of a cementless stem varies between subjects as much as between activities. Journal of biomechanics, 36(6), pp.777-785. Available at: https://doi.org/10.1016/S0021-9290(03)00011-3. 
-Pratt \& Whitney, 2002. Turbojet Engine - Standard Practices Manual (PN 582005), East Hartford, USA, Pratt \& Whitney.

Xia, Z., Ricciardi, B.F., Ba, Z.L, von Ruhland, C., Ward, M., Lord, A., Hughes, L., Goldring, S.R., Purdue, E., Murray, D., \& Perino, G. 2017. Nanoanalyses of wear particles from metal-on-metal and non-metal-on-metal dual modular neck hip arthroplasty. Nanomedicine, Nanotechnology, Biology and Medicine 13(3), pp.1205-1217.

Available https://doi.org/10.1016/j.nano.2016.11.003.

ХАРАКТЕРИСТИКИ КОМПОЗИТНОГО ПОКРЫТИЯ VРS-Ті/ТіС, НАНЕСЕННОГО ВОЗДУШНО-ПЛАЗМЕННЫМ НАПЫЛЕНИЕМ

Михаило Р. Мрдак

Центр исследований и развития А.О. «ИМТЕЛ коммуникации»,

г. Белград, Республика Сербия

ОБЛАСТЬ: химические технологии

ВИД СТАТЬИ: оригинальная научная статья

ЯЗЫК СТАТЬИ: английский

Резюме:

В данной статье представлены характеристики композитного покрытия VPS - Ti/TiC. В иели предотвращения воздействия окружающей среды на оксидацию покрытия, порошок был нанесен под низким давлением c помощью плазматрона «F4» om производителя «Plasma Technik AG». Цель настоящего исследования заключалась в предотвращении разложения кубического карбида TiC на оксиды TiO2 и NiTiO3, которые снижают: адгезию, прочность сцепления, твердость ТіС и износостойкость покрытия. $B$ статье приведен анализ механических характеристик и структуры покрытия Tі/TіC в соответствии с требованиями стандарта Pratt \& Whitney. Микротвердость слоев покрытия была в пределах 750 - 837 HV0.3, а твердость сцепления покрытия с основой составляла $84 \mathrm{MPa}$. Микроструктура покрытия испытана $c$ помощью световой микроскопии. Распределение TiC в основе Tі было равномерным, а в нанесенных слоях покрытия не было эфффектов сегрегации. Структура покрытия состоит из слоев титана с $\beta$ - Ti і $\alpha-\mathrm{Ti}$ модификациями и слоев кубического ТіС. В микроструктуре покрытия выявлено небольшое количество нерасплавленных частии TiC, а также микропоры, которые не влияют на твердость покрытия. Испытания показали, что композитное покрытие VPS - Ti/TiC обладает благоприятными механическими свойствами и микроструктурой, благодаря которым данный вид покрытия можно применять в изготовлении медицинских имплантов.

Ключевые слова: микроструктура, покрытия. 
КАРАКТЕРИСТИКЕ КОМПОЗИТНЕ ПРЕВЛАКЕ VРS - Ті/ТіС НАНЕТЕ ВАКУУМ ПЛАЗМА СПРЕЈОМ

Михаило Р. Мрдак

Истраживачки и развојни центар ИМТЕЛ комуникације а.д., Београд,

Република Србија

ОБЛАСТ: хемијске технологије

ВРСТА ЧЛАНКА: оригинални научни чланак

ЈЕЗИК ЧЛАНКА: енглески

Сажетак:

У раду су представљене карактеристике композитне превлаке VPS - Ti/TiC. Прах је депонован на ниском притиску плазма пиштољем F4, фрирме Plasma Technik AG, због утицаја околине на оксидацију праха. Циљ је био да се на ниском притиску спречи разградња кубног карбида TiC у оксиде $\mathrm{TiO}_{2}$ и $\mathrm{NiTiO}_{3}$ који умањују: адхезију, кохезиону чврстоћу, тврдоћу TiC и отпорност превлаке на хабање. Анализиране су механичке карактеристике и структура Ti/TiC превлаке у складу са стандардом Pratt \& Whitney. Muкротврдоће слојева превлаке биле су у распону од 750 до $837 \mathrm{HV}_{0.3}$, а чврстоћа споја између превлаке и подлоге имала је вредност $84 \mathrm{MPa}$. Микроструктура превлаке испитана је техником светлосне микроскопије. Дистрибуција TiC у основи Ті је равномерна, а депоновани слојеви добијени су без ефеката сегрегације. Структура превлаке састоји се од слојева титана са $\beta$ - Ti u $\alpha$ - Ti модификацијама и слојева кубног ТіС. У микроструктури су у мањем делу присутне неистопљене честице TiC и микропоре које нису утицале на чврстоћу превлаке. Испитивања су показала да композитна превлака VPS - Ti/TiC има добре механичке особине и микроструктуру, које у потпуности омогућавају њену примену на субстратима биомедицинских имплантата.

Кључне речи: микроструктура, превлаке.

Paper received on / Дата получения работы / Датум пријема чланка: 10.10.2017. Manuscript corrections submitted on / Дата получения исправленной версии работы / Датум достављања исправки рукописа: 11.11.2017.

Paper accepted for publishing on / Дата окончательного согласования работы / Датум коначног прихватања чланка за објављивање: 13.11.2017.

(c) 2018 The Author. Published by Vojnotehnički glasnik / Military Technical Courier (www.vtg.mod.gov.rs, втг.мо.упр.срб). This article is an open access article distributed under the terms and conditions of the Creative Commons Attribution license (http://creativecommons.org/licenses/by/3.0/rs/).

() 2018 Автор. Опубликовано в «Военно-технический вестник / Vojnotehnički glasnik / Military Technical Courier» (www.vtg.mod.gov.rs, втг.мо.упр.срб). Данная статья в открытом доступе и распространяется в соответствии с лицензией «Creative Commons» (http://creativecommons.org/licenses/by/3.0/rs/).

(c) 2018 Аутор. Објавио Војнотехнички гласник / Vojnotehnički glasnik / Military Technical Courier (www.vtg.mod.gov.rs, втг.мо.упр.срб). Ово је чланак отвореног приступа и дистрибуира се у складу са Creative Commons licencom (http://creativecommons.org/licenses/by/3.0/rs/). 